\title{
Front Matter: Volume 7294
}

, "Front Matter: Volume 7294," Proc. SPIE 7294, Nondestructive Characterization for Composite Materials, Aerospace Engineering, Civil Infrastructure, and Homeland Security 2009, 729401 (17 April 2009); doi: 10.1117/12.832197

Event: SPIE Smart Structures and Materials + Nondestructive Evaluation and Health Monitoring, 2009, San Diego, California, United States 


\title{
PROCEEDINGS OF SPIE
}

\section{Nondestructive Characterization for Composite Materials, Aerospace Engineering, Civil Infrastructure, and Homeland Security 2009}

\author{
H. Felix Wu \\ Aaron A. Diaz \\ Peter J. Shull \\ Dietmar W. Vogel \\ Editors
}

9-11 March 2009

San Diego, California, United States

Sponsored by

SPIE

Cosponsored by

American Society of Mechanical Engineers (United States)

Cooperating Organizations

Intelligent Materials Forum (Japan)

Jet Propulsion Laboratory (United States)

National Science Foundation (United States)

Published by

SPIE 
The papers included in this volume were part of the technical conference cited on the cover and title page. Papers were selected and subject to review by the editors and conference program committee. Some conference presentations may not be available for publication. The papers published in these proceedings reflect the work and thoughts of the authors and are published herein as submitted. The publisher is not responsible for the validity of the information or for any outcomes resulting from reliance thereon.

Please use the following format to cite material from this book:

Author(s), "Title of Paper," in Nondestructive Characterization for Composite Materials, Aerospace Engineering, Civil Infrastructure, and Homeland Security 2009, edited by H. Felix Wu, Aaron A. Diaz, Peter J. Shull, Dietmar W. Vogel, Proceedings of SPIE Vol. 7294 (SPIE, Bellingham, WA, 2009) Article CID Number.

ISSN 0277-786X

ISBN 9780819475541

Published by

SPIE

P.O. Box 10, Bellingham, Washington 98227-0010 USA

Telephone +1 3606763290 (Pacific Time) · Fax +1 3606471445

SPIE.org

Copyright ( 2009, Society of Photo-Optical Instrumentation Engineers

Copying of material in this book for internal or personal use, or for the internal or personal use of specific clients, beyond the fair use provisions granted by the U.S. Copyright Law is authorized by SPIE subject to payment of copying fees. The Transactional Reporting Service base fee for this volume is $\$ 18.00$ per article (or portion thereof), which should be paid directly to the Copyright Clearance Center (CCC), 222 Rosewood Drive, Danvers, MA 01923. Payment may also be made electronically through CCC Online at copyright.com. Other copying for republication, resale, advertising or promotion, or any form of systematic or multiple reproduction of any material in this book is prohibited except with permission in writing from the publisher. The CCC fee code is 0277-786X/09/\$18.00.

Printed in the United States of America.

Publication of record for individual papers is online in the SPIE Digital Library.

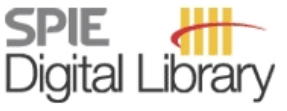

SPIEDigitalLibrary.org

Paper Numbering: Proceedings of SPIE follow an e-First publication model, with papers published first online and then in print and on CD-ROM. Papers are published as they are submitted and meet publication criteria. A unique, consistent, permanent citation identifier (CID) number is assigned to each article at the time of the first publication. Utilization of CIDs allows articles to be fully citable as soon they are published online, and connects the same identifier to all online, print, and electronic versions of the publication. SPIE uses a six-digit CID article numbering system in which:

- The first four digits correspond to the SPIE volume number.

- The last two digits indicate publication order within the volume using a Base 36 numbering system employing both numerals and letters. These two-number sets start with 00, 01, 02, 03, 04, $05,06,07,08,09,0 A, 0 B \ldots$. OZ, followed by 10-1Z, 20-2Z, etc.

The CID number appears on each page of the manuscript. The complete citation is used on the first page, and an abbreviated version on subsequent pages. Numbers in the index correspond to the last two digits of the six-digit CID number. 


\section{Contents}

vii Symposium Committee

ix Conference Committee

xiii Introduction

$\mathrm{xv} \quad$ Paleoaerodynamic exploration of the evolution of nature's flyers and man's aircraft and options for future technology innovations (Plenary Paper) [7288-104]*

B. M. Kulfan, The Boeing Co. (United States)

*This is an abridged version of Brenda Kulfan's plenary paper. A full-length version, including

figures, is published in volume 7288. The CID number is 728803.

\section{PLENARY SESSION}

729402 NDE simulations: critical tools in the integration of NDE and SHM (Plenary Paper) [7294-49] R. B. Thompson, lowa State Univ. (United States)

\section{SESSION 1 ACOUSTIC-ULTRASOUND CHARACTERIZATION I}

729403 A 35 MHz PCMUT phased array for NDE ultrasound [7294-01]

K. Snook, X. Jiang, TRS Technologies, Inc. (United States); C. Hu, Univ. of Southern California (United States); X. Geng, Blatek, Inc. (United States); R. Liu, Univ. of Southern California (United States); J. Welter, Wright Patterson Air Force Base (United States); K. Shung, Univ. of Southern California (United States); W. S. Hackenberger, TRS Technologies, Inc. (United States)

729404 Ultrasonic array speckle image correlation for internal strain and displacement measurement in metals [7294-02]

A. Bowler, B. W. Drinkwater, P. D. Wilcox, Univ. of Bristol (United Kingdom)

729405 Design considerations for the acoustic emission testing of large composite specimens [7294-03]

J. J. Scholey, P. D. Wilcox, M. R. Wisnom, Univ. of Bristol (United Kingdom); M. I. Friswell, Swansea Univ. (United Kingdom)

729406 Identification of subsurface damage in concrete using one sided wave measurements [7294-04]

D. G. Aggelis, T. E. Matikas, Univ. of loannina (Greece)

\section{SESSION 2 ACOUSTIC-ULTRASOUND CHARACTERIZATION II}

729407 Acoustic emission of steel-fiber concrete under four-point bending [7294-05]

D. G. Aggelis, D. Soulioti, N. M. Barkoula, A. S. Paipetis, T. E. Matikas, Univ. of loannina (Greece); T. Shiotani, Kyoto Univ. (Japan) 
729408 A practical approach for quantifying acoustic emission signals using diffuse field measurements [7294-06]

J. J. Scholey, P. D. Wilcox, Univ. of Bristol (United Kingdom)

729409 Multi-stage fatigue life monitoring on quasi-isotropic carbon fibre reinforced polymers enhanced with multi-wall carbon nanotubes: parallel use of electrical resistance, acoustic emission, and acousto-ultrasonic techniques [7294-07]

V. Kostopoulos, A. Vavouliotis, T. Loutas, P. Karapappas, Univ. of Patras (Greece)

\section{SESSION 3 DAMAGE CHARACTERIZATION IN COMPOSITES}

$7294 \mathrm{OE}$ Characterization of impact damage in woven fiber composites using fiber Bragg grating sensing and NDE [7294-12]

C. Hiche, K. C. Liu, Arizona State Univ. (United States); M. Seaver, Naval Research Lab. (United States); J. Wei, A. Chattopadhyay, Arizona State Univ. (United States)

7294 OF Characterization of interphase environmental degradation at elevated temperature of fiber-reinforced TMCs [7294-13]

T. E. Matikas, Univ. of loannina (Greece)

$7294 \mathrm{OH}$ Fast inverse identification of delamination of E-glass/epoxy laminated composite panels [7294-15]

G.-J. Yun, S. Shang, Univ. of Akron (United States); P. Qiao, Washington State Univ. (United States)

7294 Ol Damage severity estimate for sandwich panels with lattice core using substructure potential energy [7294-16]

H. Fang, Xi'an Jiaotong Univ. (China)

7294 0J Mechanical analysis of confectioning flaw of refractory alloy honeycomb sandwich structure [7294-17]

X. He, X. Kong, L. Shi, M. Li, Harbin Institute of Technology (China)

7294 OK The effective mechanical properties and the interfacial characterization of CNT reinforced nanocomposites [7294-18]

H. Sadeghi, R. Naghdabadi, Sharif Univ. of Technology (Iran, Islamic Republic of)

\section{SESSION 4 CIVIL INFRASTRUCTURE HEALTH MONITORING I}

$7294 \mathrm{OL}$ Overview of a cyber-enabled wireless monitoring system for the protection and management of critical infrastructure systems (Invited Paper) [7294-19]

J. P. Lynch, V. Kamat, V. C. Li, M. Flynn, D. Sylvester, K. Najafi, T. Gordon, Univ. of Michigan (United States); M. Lepech, LFL Associates (United States); A. Emami-Naeini, A. Krimotat, SC Solutions (United States); M. Ettouney, Weidlinger Associates (United States); S. Alampalli, Prospect Solutions (United States); T. Ozdemir, Monarch Antenna (United States)

7294 OM A pragmatic risk-based approach to prioritizing bridges [7294-20] F. L. Moon, Drexel Univ. (United States); J. Laning, D. S. Lowdermilk, Pennoni Associates, Inc. (United States); S. Chase, Univ. of Virginia (United States); J. Hooks, Highway Research and Development (United States); A. E. Aktan, Drexel Univ. (United States) 
7294 ON Detection and monitoring of FRP-concrete debonding using distributed fiber optic strain sensor [7294-21]

M. Imai, M. Feng, Univ. of California, Irvine (United States)

\section{SESSION $5 \quad$ CIVIL INFRASTRUCTURE HEALTH MONITORING II}

$729400 \quad$ Field experiment on monitoring of cracks in highway asphalt overlay [7294-22]

F. Lu, Southeast Univ. (China); M. Q. Feng, Univ. of California, Irvine (United States); X. Gu, S. Yang, Southeast Univ. (China)

7294 OP Monitoring a post-tensioned concrete box girder bridge with cracks [7294-23]

J. Yim, Univ. of Illinois at Chicago (United States); Y. Cao, M. L. Wang, Northeastern Univ. (United States)

\section{SESSION $6 \quad$ RADAR NDE TECHNOLOGIES}

7294 OS Determining the optimal parameters in a distant radar NDE technique for debonding detection of GFRP-concrete systems [7294-26]

T.-Y. Yu, Univ. of Massachusetts, Lowell (United States)

7294 OT Electromagnetic acoustic transduction using a pulsed electromagnet [7294-27] S. B. Palmer, J. F. Hernandez-Valle, S. Dixon, The Univ. of Warwick (United Kingdom)

7294 OV Prediction of GPR performance in landmine detection [7294-29]

M. Riahi, A. Tavangar, Iran Univ. of Science and Technology (Iran, Islamic Republic of)

\section{SESSION 7 THERMOGRAPHIC IMAGING}

7294 OX Monitoring the fracture behavior of SiCp/Al alloy composites using infrared lock-in thermography [7294-32]

E. Z. Kordatos, Univ. of loannina (Greece); D. P. Myriounis, Univ. of loannina (Greece) and Sheffield Hallam Univ. (United Kingdom); S. T. Hasan, Sheffield Hallam Univ. (United Kingdom); T. E. Matikas, Univ. of loannina (Greece)

7294 OY Investigation of alternative excitation sources for vibrothermography [7294-33] M. Genest, F. Mabrouki, A. Fahr, National Research Council Canada (Canada); N. Mrad, Defence Research and Development Canada (Canada)

$7294 \mathrm{OZ}$ Estimation of moisture and oil content of in-shell nuts with a capacitance sensor using discrete wavelet analysis [7294-34]

C. V. Kandala, J. Sundaram, USDA Agricultural Research Service (United States); K. N. Govindarajan, Univ. of Nebraska (United States); C. L. Butts, USDA Agricultural Research Service (United States); J. Subbiah, Univ. of Nebraska (United States)

729411 Optimisation of sonic thermographic inspection [7294-48] K. A. Tsoi, K. Yousif, N. Rajic, I. Powlesland, Defence Science and Technology Organisation (Australia) 
729412 Low frequency fiber optic accelerometer for civil structural health monitoring [7294-41]

I. Talebinejad, C. Fischer, F. Ansari, Univ. of Illinois at Chicago (United States)

\section{SESSION 9 FIBER OPTIC SENSING TECHNOLOGIES II}

729415 Sensitivity enhancement of fiber optic FBG sensor for acoustic emission [7294-44]

D.-C. Seo, D.-J. Yoon, I.-B. Kwon, S.-S. Lee, Korea Research Institute of Standards and Science (Korea, Republic of)

729416 Damage propagation monitoring and fatigue properties of parallel wire cable [7294-45] C. Lan, W. Zhou, H. Li, Harbin Institute of Technology (China)

729417 Measurement of surface resistivity/conductivity of Si waver by optical interferometry techniques [7294-46]

K. Habib, Kuwait Institute for Scientific Research (Kuwait); S. Habib, Kuwait Univ. (Kuwait)

729418 Health monitoring system using FBG-based sensors for the ice loading on bridge pier model [7294-47]

D. Zhang, L. Ren, H.-N. Li, Dalian Univ. of Technology (China)

\section{SESSION 10 WIRELESS SENSOR NETWORKS}

729419 Experimental study on the behavior of segmented buried concrete pipelines subject to ground movements [7294-36]

J. Kim, J. P. Lynch, R. L. Michalowski, Univ. of Michigan (United States); R. A. Green, Virginia Polytechnic Institute and State Univ. (United States); M. Pour-Ghaz, W. J. Weiss, Purdue Univ. (United States); A. Bradshaw, Merrimack College (United States)

7294 1A A prototype mobile sensor network for structural health monitoring [7294-37]

D. Zhu, Georgia Institute of Technology (United States); Q. Qi, Tsinghua Univ. (China);

Y. Wang, K.-M. Lee, S. Foong, Georgia Institute of Technology (United States)

7294 1B Smart patch for monitoring the integrity of steel frame joints [7294-38]

H. Chung, S. Beard, C. Zhang, C. Aquino, Acellent Technologies, Inc. (United States);

J. Mapar, Dept. of Homeland Security (United States)

7294 1C Experimental structural health monitoring of Z-fibre reinforced co-cured composite pi-joints using Lamb wave propagation [7294-39]

H. Kapoor, Virginia Polytechnic Institute and State Univ. (United States); S. R. Soni, Air Force Institute of Technology (United States)

7294 1D Piezoelectric based sensing in wireless steel bridge health monitoring [7294-50]

L. Yu, V. Giurgiutiu, P. Ziehl, Univ. of South Carolina (United States); D. Ozevin, Physical

Acoustics Corp. (United States)

Author Index 


\title{
Symposium Committee
}

\author{
Symposium Chairs
}

Alison B. Flatau, University of Maryland, College Park (United States)

George Y. Baaklini, NASA Glenn Research Center (United States)

Donald J. Leo, Virginia Polytechnic Institute and State University

(United States)

Kara J. Peters, North Carolina State University (United States)

Executive Committee

Mehdi Ahmadian, Virginia Polytechnic Institute and State University (United States)

Yoseph Bar-Cohen, Jet Propulsion Laboratory (United States)

Jung-Chih Chiao, The University of Texas at Arlington (United States)

Aaron A. Diaz, Pacific Northwest National Laboratory (United States)

Wolfgang Ecke, Institut für Physikalische Hochtechnologie e.V. (Germany)

Mehrdad N. Ghasemi-Nejhad, University of Hawaili at Manoa (United States)

Victor Giurgiutiu, University of South Carolina (United States)

Benjamin K. Henderson, Air Force Research Laboratory (United States)

Kumar V. Jata, Air Force Research Laboratory (United States)

Tribikram Kundu, The University of Arizona (United States)

Jiangyu Li, University of Washington (United States)

Douglas K. Lindner, Virginia Polytechnic Institute and State University (United States)

M. Brett McMickell, Honeywell, Inc. (United States)

Norbert Meyendorf, University of Dayton (United States)

Zoubeida Ounaies, Texas A\&M University (United States)

Peter J. Shull, The Pennsylvania State University (United States)

Kyo D. Song, Norfolk State University (United States)

Masayoshi Tomizuka, University of California, Berkeley (United States)

Vijay K. Varadan, University of Arkansas (United States)

Dietmar W. Vogel, Fraunhofer-Institut für Zuverlässigkeit und Mikrointegration (Germany)

Thomas Wallmersperger, Universität Stuttgart (Germany)

H. Felix Wu, National Institute of Standards and Technology (United States)

Chung-Bang Yun, Korea Advanced Institute of Science and Technology (Korea, Republic of) 
Downloaded From: https://www.spiedigitallibrary.org/conference-proceedings-of-spie on 26 Apr 2023

Terms of Use: https://www.spiedigitallibrary.org/terms-of-use 


\title{
Conference Committee
}

\author{
Conference Chair
}

H. Felix Wu, National Institute of Standards and Technology (United States)

\section{Conference Cochairs}

Aaron A. Diaz, Pacific Northwest National Laboratory (United States)

Peter J. Shull, The Pennsylvania State University (United States)

Dietmar W. Vogel, Fraunhofer-Institut für Zuverlässigkeit und Mikrointegration (Germany)

Program Committee

A. Emin Aktan, Drexel University (United States)

Farhad Ansari, University of Illinois at Chicago (United States)

Mauro J. Atalla, United Technologies Research Center (United States)

George Y. Baaklini, NASA Glenn Research Center (United States)

Yoseph Bar-Cohen, Jet Propulsion Laboratory (United States)

Oral Buyukozturk, Massachusetts Institute of Technology (United States)

Fu-Kuo Chang, Stanford University (United States)

Howard Chung, Acellent Technologies, Inc. (United States)

Maria Q. Feng, University of California, Irvine (United States)

Masoud Ghandehari, Polytechnic Institute of New York University (United States)

Hamid Ghasemi, Federal Highway Administration (United States)

Andrew L. Gyekenyesi, NASA Glenn Research Center (United States)

Clem Hiel, Composite Support and Solutions, Inc. (United States)

Xiaoning Jiang, TRS Technologies, Inc. (United States)

Anne S. Kiremidjian, Stanford University (United States)

Amrita Kumar, Florida State University (United States)

Garo K. Kiremidjian, Sensametrics, Inc. (United States)

Stephen K. L. Lee, Hong Kong University of Science and Technology (Hong Kong China)

James C. Leslie, Advanced Composite Products and Technology, Inc. (United States)

Jerome P. Lynch, University of Michigan (United States)

Richard E. Martin, Cleveland State University (United States)

Theodore E. Matikas, University of loannina (Greece)

Xiaolin Meng, The University of Nottingham (United Kingdom)

Aftab A. Mufti, University of Manitoba (Canada)

Didem Ozevin, Physical Acoustics Corporation (United States) 
Masanobu Shinozuka, University of California, Irvine (United States)

Kurt L. Silvers, Pacific Northwest National Laboratory (United States)

Lizhi Sun, University of California, Irvine (United States)

Bernhard R. Tittmann, The Pennsylvania State University (United States)

Brian J. Tucker, Pacific Northwest National Laboratory (United States)

Ming L. Wang, Northeastern University (United States)

Yang Wang, Georgia Institute of Technology (United States)

Glenn A. Washer, University of Missouri, Columbia (United States)

Tzu-Yang Yu, University of Massachusetts, Lowell (United States)

Ying Zhang, Georgia Institute of Technology, Savannah (United States)

\section{Session Chairs}

1 Acoustic-Ultrasound Characterization I

Jerome P. Lynch, University of Michigan (United States)

Xiaoning Jiang, TRS Technologies, Inc. (United States)

2 Acoustic-Ultrasound Characterization II

Jerome P. Lynch, University of Michigan (United States)

Xiaoning Jiang, TRS Technologies, Inc. (United States)

3 Damage Characterization in Composites

Masoud Ghandehari, Polytechnic Institute of New York University

(United States)

Fu-Kuo Chang, Stanford University (United States)

4 Civil Infrastructure Health Monitoring I

A. Emin Aktan, Drexel University (United States)

Hamid Ghasemi, Federal Highway Administration (United States)

$5 \quad$ Civil Infrastructure Health Monitoring II

A. Emin Aktan, Drexel University (United States)

Hamid Ghasemi, Federal Highway Administration (United States)

$6 \quad$ Radar NDE Technologies

Maria Q. Feng, University of California, Irvine (United States)

Tzu-Yang Yu, University of Massachusetts, Lowell (United States)

$7 \quad$ Thermographic Imaging

Ming Wang, Northeastern University (United States)

Ying Zhang, Georgia Institute of Technology (United States)

8 Fiber Optic Sensing Technologies I

Farhad Ansari, University of Illinois at Chicago (United States)

Yang Wang, Georgia Institute of Technology (United States) 
9 Fiber Optic Sensing Technologies II

Farhad Ansari, University of Illinois at Chicago (United States)

Yang Wang, Georgia Institute of Technology (United States)

10 Wireless Sensor Networks

Ming Wang, Northeastern University (United States)

Ying Zhang, Georgia Institute of Technology, Savannah (United States)

11 Special Panel: Critical National Needs in Civil Infrastructure

H. Felix Wu, National Institute of Standards and Technology (United States)

A. Emin Aktan, Drexel University (United States) 
Downloaded From: https://www.spiedigitallibrary.org/conference-proceedings-of-spie on 26 Apr 2023

Terms of Use: https://www.spiedigitallibrary.org/terms-of-use 


\section{Introduction}

Conference 7294, Nondestructive Characterization for Composite Materials, Aerospace Engineering, Civil Infrastructure, and Homeland Security III, was held from March 9 to 11, at the 2009 SPIE Smart Structures/NDE Symposium and contained 11 sessions including Acoustic-Ultrasound Characterization; Damage Characterization in Composites; Civil Infrastructure Health Monitoring; Radar NDE Technologies; Thermographic Imaging; Fiber Optic Sensing Technologies; Wireless Sensor Networks, and the Special Panel: Critical National Needs in Civil Infrastructure. The conference was very well received and had good attendance.

On behalf of conference chairs of conference 7294, I wanted to thank you with my whole heart for all your support and enthusiasm by submitting your high quality papers and serving as session chairs to make our conference shine at the SPIE Smart Structures/Nandestructive Evaluation for Health Monitoring + Diagnostics 2009. Indeed, we had a very successful conference this year. In addition, we had a full-house for our invited paper (given by Prof. Jerry Lynch, University of Michigan) and the Special Panel session (moderated by Prof. Emin Aktan, Drexel University). I hope you all enjoyed the conference that we put together. Thank you for all your hard work and excellent contributions. I cannot express anything more, but sincerely wish all of you will continue to support our next year's conference.

Professor Peter Shull of Penn State University will be the conference chair for 2010. Dr. Aaron Diaz and I will serve as conference co-chairs to support him. I encourage all of you to continue offering your support to Peter. I sincerely look forward to having another successful SPIE conference in 2010.

\section{H. Felix Wu}


Downloaded From: https://www.spiedigitallibrary.org/conference-proceedings-of-spie on 26 Apr 2023

Terms of Use: https://www.spiedigitallibrary.org/terms-of-use 